WINFRED SEELISCH (Durnstadt)

\title{
LOSY EMIGRANTÓW W PALESTYNIE / IZRAELU
}

Panie i Panowie, pozwólcie, że zacznę swój wywód uwagą wstępną poprzedzającą wstęp właściwy. Przedmiotem mojego wystąpienia jest próba przywołania do pamięci tła, na którym odbywała się ucieczka z Europy Wschodniej, krótki szkic politycznych uwarunkowań w kraju docelowym, tzn. w Palestynie, informacja o możliwościach ucieczki oraz, krótko reasumując, w jakich warunkach odbywał się start w nowe życie w Palestynie/Izraelu.

Wykład, podzielony jest na:

0: Uwagi wstępne,

I: $\quad$ Ruchy migracyjne (alija),

II.1: Sytuacja w Palestynie,

II.2: $\quad$ Sytuacja w Europie Środkowej,

III: Drogi ucieczki / Przeżycie w czasie shoah,

IV: Warunki startu.

\section{Uwagi wstępne}

Poniższe wywody bazu ją na literaturze, dokumentach i serii wywiadów, które miałem możliwość zebrać, wzgl. przeprowadzić, w ramach dwóch dłuższych pobytów w Izraelu latem i jesienią roku 1991 i w semestrze zimowym 1996/97 (urlop naukowy). Są one streszczeniem dłuższej rozprawy, która zostanie opublikowana $\mathrm{w}$ tym roku.

Zainspirowany rozmowami prowadzonymi z Ester Golan w roku 1989¹, podążam za wyłaniającym się wówczas pytaniem:

1 Por. K. Eich, W. Seelisch, Ester Golan - Erinnern als Aufgabe, Doron Kiesel / 
Co stało się z emigrantami do Palestyny, wzgl. do Izraela, którzy przeżyli shoah, ale których losy tylko częściowo lub też wcale nie odpowiadały temu, co uważano za pozytywny przykład kształtujący nową żydowską wspólnotę, na który powoływano się w Jishuw ${ }^{2}$, i który po utworzeniu państwa stawiano przed oczyma młodzieży izraelskiej? Są to historie życia, które nie równają się historii bojowników getta, bohaterów shoah, pierwszych pionierów, kibucników, bohaterów ruchu niepodległościowego i wojny wyzwoleńczej oraz - po procesie Eichmanna w roku 1961 - historii tych, którzy przeżyli obozy zagłady.

Co stało się z imigrantami, którzy jako dzieci, młodzież lub młodzi dorośli przeżyli. znajdując się w dowolnym miejscu na ziemi, podczas kiedy ich rodzeństwo, rodzice, krewni zostali zamordowani w Auschwitz, Majdanku, Theresienstadt? Co stało się z pokoleniem noszącym niewidzialne znamię shoah?

$\mathrm{Z}$ wydanych w ostatnich latach w języku niemieckim i angielskim autobiografii i zbiorów wywiadów z ludźmi, którzy przeżyli shoah, można pozyskać poszczególne puzzle tej historii.

\section{Wędrówki do Palestyny w XIX i XX wieku}

Pod koniec XIX wieku możemy zaobserwować wzmożone wędrówki Żydów do Palestyny z powodów religijnych. Wracają do „kraju ojców”, aby się tam modlić, umrzeć i zostać pochowanym w Ziemi Świętej. Ochrona udzielona przez państwa europejskie, których są obywatelami, umożliwia stosunkowo bezpieczne życie w Imperium Osmańskim ${ }^{3}$.

Około roku 1880 w Palestynie mieszka szacunkowo ok. 25.000 Żydów, w Europie Zachodniej i Wielkiej Brytanii ponad 200.000. W trzech cesarstwach: w Niemczech, Austro-Węgrzech i w Rosji oraz krajach bałkańskich

Ernst Karpf (Wyd.): Identität und Erinnerung. Zur Bedeutung der Shoah für die israelische Gesellschaft, Arnoldshainer Texte - t. 65, Frankfurt 1990, s. 12-28 oraz E. Golan, Auf Wiedersehen in unserem Land, Düsseldorf 1995.

2 Jishuw = organizacja wspólnoty syjonistów w Palestynie od czasu pierwszego alijah. 23.08.1903 r. zbiera się pierwsze zgromadzenie Jishuw (Knessiat Hajiischuw) w Sichron Jaakow: por.: M. Wolffsohn, D. Bokovoy, Israel. Grundwissen - Länderkunde. Geschichte, Politik, Gesellschaft, Wirtschaft (1882-1994), wyd. 4, zmienione, Opladen 1995, s. 59 .

3 Por. M. Wolffsohn, Wem gehört das heilige Land? Die Wurzeln des Streits zwischen Juden und Arabern, Monachium 1992, s. 236. 
społeczność żydowska szacowana jest na ponad 6 milionów mieszkańców, co stanowi ponad 80 procent całości jej populacji. Ok. 3 milionów Żydów mieszka w Rosji. W USA osiadło w tym czasie 300.000 ludzi wyznania żydowskiego ${ }^{4}$.

Zamordowanie przez anarchistów cara Aleksandra II wyzwala w Rosji ponowną falę pogromów i pierwszą większą falę emigracji do Palestyny. Hasło pierwszej alija $\left(1880-1903=20-30\right.$ tys. osób $\left.{ }^{5}\right)$ brzmi: „Wyruszmy do Sy jonu, z powrotem do Syjonu” i zostało zapożyczone z Biblii: „Wyruszmy (do Syjonu), synowie (i córki) Dawida". Od pierwszych liter tego cytatu biblijnego w języku hebrajskim utworzono nazwę grupową uczestników alija: BILU. Udają się do Palestyny, aby tam przeżyć i założyć pobożną żydowską wspólnotę. Nie noszą się z zamiarem utworzenia państwa ${ }^{6}$.

Druga alija zaczyna się w latach 1904-1905 i trwa do 1914 r. (40.000 osób ${ }^{7}$ ). Jej tłem jest $\mathrm{z}$ jednej strony rewolucja rosy jska roku 1905 i powiązane z nią prześladowania aktywistów żydowsko-socjalistycznych, a następnie pogromy. Z drugiej strony tworzy je polityczny syjonizm, będący narodowo-żydowską odpowiedzią na nacjonalistyczne wyzwania schyłku XIX wieku w Europie. Pisząc o jego korzeniach można wymienić takie nazwiska, jak: Moses Hess, Leon Pinsker, Theodor Herzl i Chaim Weizmann oraz hasła: Kongres Syjonistyczny, Światowa Organizacja Syjonistyczna (powstała w celu wyłonienia publiczno-prawnego miejsca schronienia dla narodu żydowskiego w Palestynie), Poale Syjon (Robotnicy Syjonu) - założony przez partię socjalistyczną Królestwa Kongresowego, którego współpracownikiem był m.in. Ben-Gurion ${ }^{8}$.

35.000 Żydów ${ }^{9}$, którzy wyemigrowali do Palestyny w latach 1919-1923 określa się mianem trzeciej alija. Jej tłem jest polityczny rozwój sytuacji w Rosji (wojna domowa etc.), Rumunii, na Węgrzech i w Czechosłowacji. Jednocześnie organizacje syjonistyczne w Europie rozpoczynają przygotowywać swoich członków do emigracji poprzez szkolenia z zakresu rolnictwa (Haschscharah).

4 Por. R. Sanders, Shores of Refuge. A hundred Years of Jewish Emigration, New York 1988, s. XI.

5 Por. T. M. Krapf, Israel zwischen K'rieg und Frieden, Gerlingen 1996, s. 283.

6 Por. M. Wolffsohn, op. cit., s. 236-237, 240.

7 Por. T. M. Krapf, op. cit., s. 283.

8 Por. H. Haumann, Geschichte der Ostjuden, München 1990, s. 147-149.

9 Por. T. M. Krapf, op. cit., s. 283. 
Nacjonalistyczna, wroga wobec mniejszości i tym samym antysemicka postawa prawicowych partii, a częściowo również rządu polskiego, w państwie zamieszkiwanym przez wiele narodowości, wywołuje w latach 1924-1931 następną dużą falę emigracji (4 alija $=82.000$ osób $\left.{ }^{10}\right)$.

Lata 1933-1939 to piąta alija (= 200.000 osób $\left.{ }^{11}\right)$, która obejmuje przede wszystkim emigrantów z Niemiec, ale również z Polski.

W tym samym czasie rozpoczyna się alija Bet - emigracja nielegalna. Haganah oraz inne ugrupowania ściągaja do kraju emigrantów - ochotników, a po wojnie DP's (Displaced Persons) i tych, którzy przeżyli shoah. Jej symbolami są 'w roku 1934 grecki statek „Velos”, brytyjski obóz dla osób internowanych Atlit, w pobliżu Haify, a po II wojnie światowej statek "Exodus" 12.

Szósta alija (1949-1952) potroiła w ciągu kilku lat żydowską ludność Izraela. Emigrują Żydzi europejscy, z Polskiej Republiki Ludowej i Rumunii. „Z powodu wzrastającego ucisku, motywowanego politycznie, a także fascynacji na tle religijnym [...] przenoszą się do Izraela grupy ludności świata arabskiego: Irakijczycy, Jemeńczycy, Marokańczycy, Algierczycy"13.

Emigracja Żydów etiopskich (Falashas) przebiega przez izraelski most powietrzny, utrzymywany z pomocą USA i Sudanu w roku 1984 (operacja Mojżesz) i w 1991 r. podczas operacji Salomon ${ }^{14}$ (również zakrojony na szeroką skalę most powietrzny - siódma alija).

W latach 1989 do 1994/5, a właściwie do dnia dzisiejszego, przebiega 8 alija: emigracja 800 tys. $-1,1$ mln Żydów z Rosji i innych państw WNP. Powód: głasnost', rozwiązanie ZSRR, strach przed nową falą antysemityzmu ${ }^{15}$, jak i również pogarszająca się sytuacja gospodarcza dużej części społeczeństwa.

10 Ibidem.

11 Ibidem.

12 H. W. Goldstein, „Alija Bet”, „nielegalna emigracja” - ratunek dla tysięcy, „Israel Nachrichten" z 5 czerwca 1998, nr 8883, s. 4.

13 H. J. Ginsburg, Chronologie des Nahost-Konflikts, w: B. Schiller, Izrael. Ein Reisebuch, wyd. 2. Hamburg 1988, s. 161.

14 Por. M. Wolffsohn, D. Bokovoy, op. cit., s. 245.

15 Patrz: wypowiedzi Żirinowskiego podczas rosyjskich wyborów prezydenckich. 


\section{Sytuacja w Palestynie}

Na Dalekim Wschodzie, będącym oficjalnie do końca I wojny światowej częścią Imperium Osmańskiego, zderzają się ze sobą dziewiętnastowieczne idee państw narodowych - syjonizm i nacjonalizm arabski ${ }^{16}$. Są one jednocześnie konfrontowane $z$ imperializmem nacjonalistycznych mocarstw europejskich, Francji i Wielkiej Brytanii ${ }^{17}$, które usiłują utworzyć systemy hegemonialne, w celu zabezpieczenia własnych kolonii, wzgl. sieci transportowej prowadzącej do nich ${ }^{18}$.

Po I wojnie światowej Palestyna, jako mandat Ligi Narodów, przypada Wielkiej Brytanii. W akcie mandatowym Zjednoczone Królestwo zobowiązuje się, podobnie jak wcześniej w deklaracji Balfoura (1917) ${ }^{19}$, wspierać utworzenie namiastki narodowego państwa żydowskiego i z tego względu ułatwiać emigrację Żydów do Palestyny. Jewish Agency, jednostka centralna emigracji syjonistycznej, wprowadza pod hasłami „podboju pracy” i „podboju ziemi" restrukturyzację kraju o systemie feudalnym według wyobrażeń syjonistycznych ${ }^{20}$, tzn.: utworzenie namiastki narodowego państwa żydowskiego z „nowym człowiekiem żydowskim”, który realizuje się w kibu$\operatorname{cach}^{21}$, gdzie kobieta jest zrównana w prawach $\mathrm{z}$ mężczyzną ${ }^{22}$. W organach Jishuw urzeczywistnia się polityczne idee socjalistyczne. Pomocny jest przy

16 Por. M. Wolftsohn, op. cit., s. 243-246.

17 Por. H. Herzfeld, Die moderne Welt 1789-1945, II. Teil Weltmächte und Weltkriege 1890-1945, Braunschweig 1960, s. 4.

18 Por. P. Heine, Der Nahe und Mittlere Osten unter kolonialer Herrschaft, w: U. Steinbach, R. Robert, Der Nahe und Mittlere Osten. Politik ${ }^{*}$ Gesellschaft ${ }^{*}$ Geschichte * Kultur, T. I. Grundlagen, Strukturen und Problemfelder, Opladen 1988, s. 97-100.

19 W nocie angielskiego ministra spraw zagranicznych z 2.11.1917 jest mowa o poparciu dla „utworzenia namiastki narodowego państwa dla narodu żydowskiego w Palestynie” i dodaje się, że nie wydarzy się nic, co naruszy cywilne i religijne prawa istniejących tam gmin nieżydowskich. Por. N. Bethell, Das Palästina Dreieck. Juden und Araber im Kampf um das britische Mandat 1935-1948, Frankfurt 1979, s. 13. Mimo tego już w 1915 roku brytyjski wysoki komisarz w Egipcie, Sir Henry McMahon, obiecał w liście do Scherif Husseina utworzenie niezależnego królestwa arabskiego łącznie z Palestyną w celu wsparcia Wielkiej Brytanii w walce z Turcją. Por. M. Wolffsohn, op. cit., s. 244-245.

20 Por. P. Heine, op. cit., s. 123.

21 Kibuc: komuna rolna bez własności prywatnej.

22 Syjoniści z 2 i 3 alija chcieli odnowienia i uzdrowienia narodu żydowskiego przez pracę fizyczną. Miał się on stać „narodem sierpa i motyki. Praca fizyczna miała uzdrowić chorą duszę narodu żydowskiego, sprowadzić mężczyzn na powrót do ziemi, do ziemi przodków, do wspólnoty żydowskiej w Palestynie". F. Schreiber, M. Wolffsohn, Nahost. Geschichte und Struktur des Konflikts, Opladen 1988, s. 5. 
tym nowy język: hewrit, zastępu jący jidysz. Systematyczna polityka wykupu ziemi ${ }^{23}$, podział pracy pomiędzy niemal wyłącznie żydowskich emigrantów. Nacjonalizm palestyński początku XX wieku, ujawniający się w mniejszych lub większych krwawych aktach przemocy, skierowanych przeciwko pojedynczym Żydom i gminom żydowskim w Jerozolimie i innych miejscowościach, ale również napadami na kibucników, wywołuje „politykę uspokajania" brytyjskiego rządu mandatowego. Dopuszczalna ilość emigrantów żydowskich dopasowywana jest do „potrzeb politycznych”. Socjalistyczna większość $\mathrm{w}$ Jishuw stawia w tym czasie nadal na współpracę z brytyjskim rządem mandatowym i powstrzymywanie akcji odwetowych (co oznaczałoby w praktyce terror odwetowy) wobec nacjonalizmu palestyńskiego. Jedynie ugrupowania rewizjonistyczne Jabotyńskiego zwraca ją się przeciwko tej polityce i żądają postawienia żelaznej ściany ${ }^{24}$.

Przejęcie władzy przez narodowych socjalistów w Niemczech, ucisk i prześladowanie gmin żydowskich jak i również wyraźnie wzmożony antysemityzm w Polsce prowadzi do znacznego wzrostu liczby emigrantów. Owocu je to gwałtownym sporem z nacjonalistami palestyńskimi. Rząd brytyjski zmuszony jest do powołania komisji śledczej pod przewodnictwem lorda Peela w celu udania się do Palestyny i znalezienia sposobu rozwiązania konfliktu. Raport Peela zaleca podział terytorium mandatowego Palestyny. Jishuw, wzgl. egzekutywa syjonistyczna pod przewodnictwem Chaima Weizmanna i Bena Guriona, zgadzają się na plan podziału, strona palestyńska go odrzuca ${ }^{25}$; reagu je buntem przeciwko rządowi mandatowemu i napadami na osiedla żydowskie. W połowie roku 1938 powstanie przybiera formę wojny ludowej. Załamuje się ona w końcu na wiosnę 1939 roku, po wysłaniu następnej dywizji brytyjskiej do Palestyny i w wyniku wewnątrzarabskich sporów. Żydowska Haganh trzyma się w znacznym stopniu zasady samoobrony, sporadycznie współpracuje nawet $\mathrm{z}$ wojskami mandatowymi, podczas kiedy rewizjonistyczny odłam Irgun Zwai, wzgl. Etzel, odpowiada zmasowanym terrorem. Polityczną reakcją Wielkiej Brytanii jest ustanowienie następnej komisji, komisji Woodheada, której zalecenia, na tle rysującego się konfliktu z III Rzeszą, sprowadzają się do wycofania zaleceń komisji Peela: (1) Żadnego państwa żydowskiego, (2) Żadnego podziału Palestyny, (3) Drastyczne ograniczenie emigracji żydowskiej, (4) Żadnego arabskiego państwa w Pale-

\footnotetext{
23 Por. P. Heine, op. cit., s. 123.

24 Por. F. Schreiber, M. Wolffsohn, op. cit., s. 53-81.

25 Por. ibidem, s. 89-100.
} 
stynie, w zamian za to włączenie go do Federacji Arabskiejer. Raport zostaje utajniony, ale po załamaniu się powstania stanowi podstawę dla brytyjskiej Białej Księgi, wzgl. memorandum MacDonalda, tzn. oficjalnej polityki rządowej. Zawiera on treści następu jące:

- ograniczenie emigracji żydowskiej do 75.000, tak aby cała ludność żydowska wynosiła ok. 1/3 ogółu ludności,

- wyznaczenie po 5 latach arabskiego prawa weta wobec emigracji żydowskiej,

- zarządzenie Wysokiego Komisarza o ograniczeniu zakupu ziemi przez Żydów, poza wąskim pasem brzegowym wokół Haify i Tel Awiwu,

- budowa palestyńsko-żydowskich instytucji samorządowych, w celu utworzenia po 10 latach niezależnego państwa palestyńskiego z większością arabską, pod warunkiem, iż obie strony wyrażą na to zgodę ${ }^{27}$.

Zarówno strona palestyńska jak i syjonistyczna odrzucają te wyobrażenia i obierają kurs konfrontacji z władzą mandatową. Napad na Polskę wyznaczający początek II wojny światowej, a zarazem kampanii zniszczenia wymierzonej w ludność żydowską Europy, stawia Jishuw po stronie Wielkiej Brytanii: Ben Gurion oznajmia na posiedzeniu komitetu centralnego Mapai: „W tej wojnie będziemy walczyć po stronie Wielkiej Brytanii, tak jakby nie istniała «White Paper Policy» i będziemy zwalczać tę politykę, tak jakby nie było wojny." 28

Palestyńczycy, tak jak inni przywódcy arabscy, pod przewodnictwem Wielkiego Muftiego Jerozolimy Amina el-Husseini opowiadają się po stronie Niemiec.

\section{Sytuacja w Europie Środkowej}

W pierwszej połowie I wojny światowej ludność żydowska w Polsce ${ }^{29}$ jest prześladowana przez administrację rosyjską, ponieważ oskarża ona ich o współpracę z Niemcami. W następnych latach, naznaczonych bólami

26 Ibidem, s. 105.

27 Por. N. Bethell, op. cit., s. 66.

28 T. Segev, Die siebente Million. Der Holocaust und Israels Politik der Erinnerung, Deutsch von Jürgen Peter und Maja Ueberle-Paff. Reibek bei Hamburg 1995, s. 116 ( Ha-milyon ha-shevii, Jerusalem 1991 / The seventh Million. The Israelis and the Holocaust, New York 1993).

29 Mowa o terenach polskich zaanektowanych przez Rosję w roku 1792. 
świeżo powstającej państwowości, większość polskiego społeczeństwa dyskryminuje gminy żydowskie, podchodzi do nich wręcz z otwartą wrogością, kiedy próbują one (stanowiąc $10 \%$ ogółu ludności $=3.000 .000$ ) uzyskać $\mathrm{w}$ nowym państwie status mniejszości narodowej. Kiedy w związku z rokowaniami pokojowymi nowe polskie władze w ramach umów zmuszone są również do przy jęcia ustaw o ochronie mniejszości w odniesieniu do ludności żydowskiej, a Narodowi Demokraci Dmowskiego przegrywaja pierwsze wybory do Sejmu, tracąc tym samym wpływ na kierunek polityki (koncepcja jagiellońska czy piastowska ${ }^{30}$ ), wybucha otwarty antysemityzm sił „prawicowych": Narodowych Demokratów, części Stronnictwa Ludowego i wspierającego go Kościoła katolickiego oraz szerokich kręgów militarnych (generał Haller). Dopiero zamach stanu Piłsudskiego w roku 1926 i jego „narodowa dyktatura (lewicowa)" osłabia ją falę antysemityzmu. Zyskuje ona jednak znowu na sile w wyniku Wielkiego Kryzysu i przykładu jaki daja faszystowskie i faszystoidalne partie w Europie i w sąsiednich narodowosocjalistycznych Niemczech. Po śmierci charyzmatycznego Piłsudskiego ${ }^{31}$ w roku 1935 dochodzi do zbliżenia reżimu z siłami prawicowymi w kraju i w związku z tym do ponownej fali antysemityzmu. Siłą nośną jest duża część warstwy średniej i akademicy, którzy czują się najbardziej zagrożeni przez pozorną „proletaryzację". Numerus clausus i getta ławkowe dla żydowskich studentów na uniwersytecie, paragrafy aryjskie w wielu stowarzyszeniach zawodowych, bojkot jako środek w celu polonizacji gospodarki, plany w Ministerstwie Spraw Zagranicznych (wysiedlenie Żydów nie tylko do Palestyny, ale również na Madagaskar, propozycje ustaw á la Ustawy Norymberskie) - te czynniki określały życie Żydów w Polsce międzywojennej i prowadziły wielu z nich do trzeciej i czwartej alija. Kiedy po anszlusie Austrii rząd polski odbiera obywatelstwo ży jącym tam Żydom polskim, aby zapobiec ich powrotowi, rząd narodowosocjalistyczny zaostrza możliwości ustawowe wydalenia obywateli polskich. W październiku 1938 roku, podczas akcji „noc i mgła”, 17-20 tys. Żydów polskiego pochodzenia zostaje

30 Idea jagiellońska bazowała na wyobrażeniu państwa polskiego, w kształcie, w jakim istniało podczas panowania Jagiellonów w XII i XIII w. w symbiozie z Litwą; idea piastowska odwołuje się do państwa Piastów, z granicami aż na Odrze. Por. A. Uschakow (wyd.), Polen - Das Ende einer Erneuerung? Gesellschaft, Wirtschaft und Kultur im Wandel, München 1982, s. 16.

31 Piłsudski był wysoko ceniony przez Hitlera i Göringa, który w latach 1934/35 dążył do współpracy pomiędzy Polską Piłsudskiego a narodowosocjalistycznymi Niemcami. Por. A. Kube, Pour le mérite und Hakenkreuz. Hermann Göring im Dritten Reich, München 1987, s. 103-118 i S. Martens, Hermann Göring. „Erster Paladin des Führers” und „Zweiter Mann im Reich", Paderborn 1985, s. 53-60. 
odtransportowanych na granicę 32 (model późniejszych deportacji) i podejmowana jest próba wydalenia ich z Niemiec. Strona polska wzbrania się przed ich przyjęciem i po przejściu niewielkiej części zamyka granicę. Krokiem odwetowym jest wydalenie Żydów niemieckiego pochodzenia z Polski do Niemiec. „Z wściekłości spowodowanej wysiedleniem jego rodziców mieszkających w Hannoverze", którzy w strasznych warunkach przetrzymywani są na granicy, Herszel Grynszpan strzela do niemieckiego pracownika ambasady w Paryżu, von Ratha. Zamach posłuży kierownictwu narodowosocjalistycznemu jako pretekst do pogromów 9 listopada 1938 i w dniach późniejszych ${ }^{33}$.

W nowo powstałej Czechosłowacji antysemityzm szerzony przez grupy ludowe osłabiany jest przez prezydenta Masaryka. Konstytucyjnie umocowana możliwość przyznania się do narodowości żydowskiej przyczynia się do pełnego nadziei współżycia. Wszakże 1 procent ludności określa swoją narodowość jako żydowską, choć wg wyznania religijnego jest ich 2,5 procenta. Sukcesy gospodarcze i społeczno-polityczne nowego państwa polepszają poprawne współżycie i czynią z Pragi duchową i kulturową stolicę, nie tylko czeskiego, żydostwa ${ }^{34}$.

Sytuację gmin żydowskich na Węgrzech oddaje dobrze, choć w nieco przejaskrawiony sposób, następująca historia: „Żyd przywędrowuje do Mármaros. Jest tam żebrakiem, wyrobnikiem, później sprzedawcą wina. Jego syn przeprowadza się dwa komitaty dalej na Zachód i zostaje właścicielem fabryki, handlarzem, dzierżawcą. Wędrując jeszcze dwa komitaty dalej staje się posiadaczem ziemskim i nabywa zamek. W Budapeszcie ubiega się o tytuł szlachecki, fotel poselski i barona, a kiedy dorobił się już kilku milionów, przeprowadza się do Wiednia" ${ }^{35}$. Węgry są krajem migracji dla Żydów ze wschodnich terenów Europy, tutaj pełnią oni rolę pośredników pomiędzy miastem a wsią, wspierani przez liberalną szlachtę, której prowadzą interesy bankowe i nowoczesną gospodarkę rolną. Jest zjawiskiem symptomatycznym, że w handlowych skupiskach Budapesztu $35 \%$ ludności określa siebie jako zasymilowanych Żydów. Dochodzi do napięć pomiędzy Żydami „otwartymi na świat” a ugrupowaniami ortodoksyjnymi lub chasydzkimi, napięć wykorzystywanych przez grupy antysemickie, przenoszo-

\footnotetext{
32 Patrz: rozdział „Losy indywidualne”.

33 Por. H. Haumann, op. cit., s. 180.

34 Ibidem, s. 164-166.

35

Ibidem, s. 156.
} 
nych do krajów migracji i do Izraela ${ }^{36}$. Czas po I wojnie światowej charakteryzuje się $\mathrm{w}$ fazie początkowej pogromami i ekscesami związanymi z republiką szczurów (Bela Kun) ${ }^{37}$ i kontrrewolucją. Udział procentowy ludności żydowskiej na Węgrzech maleje, co uwarunkowane jest stratami terytorialnymi i spadającą liczbą urodzeń. Skupia się on w Budapeszcie, gdzie żyje 50 procent węgierskich Żydów, i stwarza poprzez zwrócenie się $\mathrm{ku}$ istocie żydostwa ogólnospołeczną akceptację. Dopiero w latach trzydziestych, pod wpływem Niemiec, akceptacja ta maleje, co znajduje swoje odbicie w mocno antysemickim ustawodawstwie. W czasach Horthy przeradza się $\mathrm{w}$ państwo faszystoidalne ${ }^{38}$, którego przejęcie przez Strzałokrzyżowców w roku 1944 (pod rządami Szálasi) otworzyło ostatecznie bramę rasizmowi.

W Rumunii, podczas I wojny światowej Żydów prześladuje się jako sympatyków lub szpiegów Monarchii Habsburskiej. Na podstawie porozumienia w Trianon, Rumunia otrzymuje od Rosji Bezarabię, od Austrii Bukowinę, a od Węgier Siedmiogród (Transylwanię), wobec czego liczba ludności żydowskiej wrasta w niej do 800.000, tj. 4,5\% całej ludności Rumunii. Pod presja Ententy również tutaj przyznaje się Żydom w 1923 roku w konstytucji Rumunii równouprawnienie. Jednak dokładnie rok później ogranicza się ich prawa, a środowisko akademickie wiedzie prym w szerzeniu hasel, że Żydzi pozbawiają Rumunów określonych pozycji. Również ze środowiska studenckiego wywodzą się pierwsi członkowie powstałych później Legionów Archanioła Gabriela, które w 1930 roku przechodzą w finansowaną ze środków niemieckich Żelazną Gwardię i próbują realizować swoje antysemickie plany (np. podczas puczu na Antonescu w 1941 r. ginie ponad 600 Żydów - pogrom w Bukareszcie) ${ }^{39}$.

Zakładam, że sytuacja ludności żydowskiej w Niemczech jest ogólnie dobrze znana, dlatego też jedynie przypomnę najważniejsze fakty czy tė̇ uchwały dotyczące ich „poniżenia i ubezwłasnowolnienia”.

Po sukcesie wyborczym NSDAP w 1930 roku i następującej po nim agitacji dochodzi do pierwszych politycznie i programowo określonych aktów przemocy i bojkotu wobec wybranych interesów właścicieli żydowskich ${ }^{40}$.

36 Patrz: rozdział „Losy indywidualne”; T. Segev, op. cit., s. 341-367.

37 Por. I. Lázár, Illustrierte Geschichte Ungarns, Budapest 1997, s. 109-111.

38 Ibidem, s. 112-118.

39 Por. H. Haumann, op. cit., s. 166.

40 Por. H. Greive, Die Juden: Grundzüge ihrer Geschichte im mittelalterlichen und neuzeitlichen Europa, wyd. 2, Darmstadt 1992. 
Po „przejęciu władzy” są to kolejno:

- po spaleniu Reichstagu 28 lutego „zarządzenie prezydenta Rzeszy o ochronie narodu i państwa" zawieszające podstawowe prawa obywatelskie, po którym następuje założenie pierwszego (nieorganizowanego i niezarządzanego centralnie) obozu koncentracyjnego ${ }^{41}$,

- od 1 kwietnia 1933 roku powszechny bojkot sklepów żydowskich,

- zarządzenie z 7.4.1933 r. o "odnowieniu stanu urzędniczego", które wyklucza $z$ tego zawodu wszystkich nie-Aryjczyków i następująca po nim uchwała „o redaktorach i izbie kultury Rzeszy”, ograniczająca działalność w całym obszarze prasy, sztuki edukacyjnej i wystawowej,

- unieważnienie, wydawanych przez kasy lekarskie, zezwoleń na wykonywanie praktyki lekarskiej w krajach związkowych - regulamin egzaminacyjny Rzeszy, zgodnie z którym począwszy od grudnia 1934 roku zabrania się między innymi habilitowania naukowców pochodzenia żydowskiego,

- 15 września 1935 roku „ustawa norymberska”, zwana ustawą obywatelską Rzeszy, wg której Żydzi nie są już uznawani za prawnych obywateli Rzeszy, lecz jedynie za "przynależnych do państwa",

- ustawa „o ochronie niemieckiej krwi i honoru”, zgodnie z którą zabranie się zawierania związków małżeńskich z Żydami i na podstawie której aryjskie pochodzenie jest warunkiem uzyskania posady w sektorze użyteczności publicznej. Przez kolejne przepisy wykonawcze wypowiada się Żydom pracę na stanowiskach radcy prawnego, ratownika, nauczyciela etc.,

- wiosną 1938 roku, przez naniesienie zmian w ustawie przemysłowej, zaczyna się wypieranie Żydów z pozostałych sektorów gospodarki niemieckiej i jednocześnie wzmożony nacisk na ich emigrację $z$ kraju. Nacisk ten wraz $\mathrm{z}$ wydarzeniami $\mathrm{z}$ „nocy kryształowej” 9 listopada i uchwalonymi podczas obrad 12 listopada ustawami, zarządzeniami i dekretami prowadzi do definitywnego końca udziału niemieckich Żydów $\mathrm{w}$ gospodarce kraju. Końcowi temu towarzyszą różnego rodzaju szkalowania i denuncjacje: żydowskim dzieciom zabrania się uczęszczać do niemieckich szkól, kierowców samochodów ciężarowych pozbawia się prawa jazdy, zakazuje się używania telefonów i słuchania radia. Pojawia się ustawa o stosunku wynajmu ułatwiająca wymowę mie-

41 Por. W. Conze, V. Hentschel (wyd.), Ploetz: deutsche Geschichte, wyd. 5 powt. i zak., Freiburg 1991, s. 268. 
szkań, a urzędy komunalne umożliwiają zakładanie specjalnych osiedli żydowskich. Od 1 stycznia 1939 roku obowiązuje nakaz dopisania przed nazwiskiem na wszystkich dowodach tożsamości imienia Sarah lub Izrael.

Wraz z przyłączeniem Austrii do Niemiec podejmuje się działania mające na celu ostateczne „uwolnienie" Rzeszy, a potem Europy z Żydów: wzmożona emigracja 1938/39 r., z początkiem wojny wydalenie do Polski, zakładanie gett w Guberni Generalnej w celu realizacji planu madagaskarskiego, ale kiedy ten, w wyniku wydarzeń na froncie, nie może zostać urzeczywistniony, po ataku na Związek Radziecki postanawia się wyniszczenie Żydów rosyjskich ${ }^{42}$, a potem niemieckich i europejskich, których ostateczną „eliminację" ustala się na konferencji w Wannsee w styczniu 1942 roku (pierwszy termin konferencji 9 grudnia 1941 r. $\left.{ }^{43}\right)^{44}$.

\section{Drogi ucieczki / przetrwanie w shoah}

Przedstawione poniżej, ogólnie podsumowane wypowiedzi mają na celu zaprezentowanie partnerów wywiadów. Również tutaj pewne kwestie zostaną tylko nadmienione, jedynie obszar tematyczny dotyczący transportu dzieci zostanie potraktowany obszerniej.

W dalszej części należy zauważyć, że potencjalne kraje imigracyjne dysponują ustaloną liczbą imigrantów, ale kiedy wzrasta ilość składanych wniosków emigracyjnych, prawie wszystkie państwa, również te „klasyczne kraje imigracyjne" jak USA i państwa Ameryki Łacińskiej redukują tę liczbę. Nawet konferencja uciekinierów w Evian les Bains w roku 1938 nie ma wpływu na zmianę postawy tych państw. Wyjątek stanowi cel ucieczki: Szanghaj

42 Heydrich jako szef RSHA «da się potwierdzić 31 lipca 1941 roku, że dokonał „wszelkich wymaganych przygotowań odnośnie wspólnego rowiązania kwestii żydowskiej w niemieckim obszarze wpływów w Europie” i „przedłoży wkrótce wspólny projekt na temat założeń organizacyjnych, rzeczowych i materialnych dotyczących ostatecznego, oczekiwanego rozwiązania kwestii żydowskiej" "IMT, tom XXVI, s. 266-267 wydrukowane w: K. Pätzold, E. Schwarz, Tagesordnung: Judenmord. Die Wannsee-Konferenz am 20. Januar 1942. Eine Dokumentation zur Organisation der „Endlösung”, wyd. 3, Berlin 1992, s. 79 .

43 Ibidem, s. 33.

44 Por. U. Adam, Die Judenpolitik des Dritten Reiches 1933-1942, w: G. B. Ginzel (wyd.), Antisemitismus. Erscheinungsformen der Judenfeindschaft gestern und heute, 1991, s. 192-218. 
i Boliwia, które w latach 1938/39 zdecydowanie podwyższają liczbę imigrantów ${ }^{45}$.

- Przetrwanie w podziemiach w jednym z zajętych przez Niemców kraju, np. w Czechosłowacji: Od roku 1943 jako dziecko lub młodociany członek grupy oporu, który wraz $\mathrm{z}$ rodzicami spędza każdą noc w innym schronieniu do momentu oswobodzenia danego obszaru przez Armię Czerwoną.

- Wyjazd lub możliwości ucieczki z Niemiec czy też z Europy Środkowej, bez związków syjonistycznych lub tylko częściowo z tymi związkami: Rodzina dostrzega nadciągające niebezpieczeństwo i pozostawiając jakąś część swojego majątku (zależnie od kraju, momentu historycznego etc.), będąc jednak dostatecznie zabezpieczona finansowo, wspólnie podejmuje decyzję o emigracji. Celem ucieczki są: USA, Palestyna lub jakiś inny kraj, który zamieszkują ich krewni. Jeśli wyjazd następuje z Niemiec, a celem jest Palestyna, to dzieje się to zgodnie $\mathrm{z}$ porozumieniem w Haawara zawartym w 1933 roku pomiędzy rządem Rzeszy a Jewish Agency (Arthur Rupin). Na podstawie tego porozumienia każdy emigrant ma prawo zabrać ze sobą do Palestyny w walucie zagranicznej 15000 marek (1000 funtów szterlingów) i wywieźć przedmioty, których łączna wartość nie przekracza 20000 marek. Przy tym należy uregulować finansową stronę, założonych tylko w tym celu, żydowskich i niemieckich spółek powierniczych. Aby uzyskać pozwolenie od brytyjskiego urzędu mandatowego na osiedlenie się w Palestynie jako kapitalista (kategoria emigracyjna), trzeba było mieć 1000 funtów szterlingów. Żydowscy emigranci zanim opuszczą Niemcy, deponują swój kapitał w niemieckiej spółce powierniczej. Spółka ta kupuje za te pieniądze u niemieckich dostawców produkty na eksport do Palestyny. Jeśli jakiś klient w Palestynie zamawia produkty $\mathrm{z}$ Niemiec, to kwestię płatności rozwiązuje przez palestyńską spółkę powierniczą, która to ze swojej strony otrzymaną gotówkę oddaje w odpowiedniej sumie przybyłym w międzyczasie Żydom z Niemiec. Kulisami tego porozumienia jest fakt, że narodowosocjalistyczne Niemcy pozbędą się dużej ilości Żydów, zwiększą eksport i przełamią bojkot gospodarczy, do którego nawoływały organizacje żydowskie, szczególnie ze Stanów Zjednoczonych. Syjonistyczny ruch po-

45 Por. W. Seelisch, Jüdische Emigration nach Bolivien Ende der 30er Jahre, w: A. Schrader, K. H. Rengstorf (wyd.), Europäische Juden in Lateinamerika. Westfälische Wilhelms-Universität Münster. Forschungsgruppe Lateinamerika, St. Ingbert 1989, s. $77-101$. 
zyskuje nowych osiedleńców, którzy nie mogliby przybyć do Palestyny bez zezwolenia na transfer kapitału. Emigranci ratu ją swoje życie i część majątku. Ów Haavara system działa do początku II wojny światowej i przyczynia się do uratowania ok. 20000 ludzi, przepływu ok. 30 milionów dolarów z Niemiec do Palestyny ${ }^{46}$.

- Bez związków syjonistycznych: Dostrzega się nadciągające niebezpieczeństwo. Członków rodziny, dzieci lub samo dziecko wysyła się do krewnych w Europie lub poza jej granice. W miejscu ucieczki zabezpiecza się odbiór i utrzymanie.

- Rodzina lub jej członkowie są pod silnym wpływem syjonizmu. Podczas Haschscharah, szkolenia na jakiejś posiadłości ziemskiej w Niemczech lub jakimś innym kraju europejskim przygotowują się do przyszłego życia w Palestynie. Do emigracji dochodzi dopiero po uzyskaniu odpowiedniego certyfikatu i w terminie wyznaczonym przez syjonistyczną organizację, do której należy się przez Haschscharah i która otrzymuje swoje "przydziały” od Jewish Agency, gdyż nie można korzystać tu z wyżej wspomnianych „wiz kapitalistów”. Po przesiedleniu do Palestyny „nowo przybyli" mieszkają w jednym $z$ należących do organizacji kibuców lub też zleca się im budowę nowego kibucu.

Po „nocy kryształowej” i następujących po niej wydarzeniach, setki tysięcy Żydów zgłasza się do założonej 24 stycznia 1939 roku w Berlinie Centrali Rzeszy dla Żydowskich Emigrantów. Restrykcyjne ustalenia emigracyjne, takie jak: narodowa liczba (urodzin), nieskazitelne, policyjne świadectwo o niekaralności versus pobyt, zaświadczenie o posiadanym kapitale versus konfiskata mienia etc., nie pozostawiały zbyt wielu możliwości emigracyjnych. Jedną z nich jest „otwarte" wówczas miasto Szanghaj. Od uciekinierów do Szanghaju nie wymaga się „ani paszportu, ani wizy na wyjazd, ani pozwolenia na pobyt, ani na pracę, ani zaświadczenia o posiadanym kapitale, ani też waluty kraju". Przybywający nie potrzebują też szukać kogoś, „...poręczyciela, który byłby gotowy do przejęcia ich utrzymania”. Jeśli uda się zdobyć bilet na rejs statkiem do Chin albo bilet na „kolej transsyberyjską", to wystarczy mieć tylko paszport, który umożliwia przekroczenie granicy Rzeszy niemieckiej i ważną wizę tranzytową. Międzynarodowy i niemiecki transport morski, ze względu na zwiększony popyt, zareagował w latach trzydziestych dodatkowymi możliwościami rejsowymi. Aby pokryć koszty rejsu, zapłacić za bilet kolejowy i przejazd, większość uciekinierów z lat 1938-1941 zmuszona jest do wyprzedaży majątku lub musi zwrócić

46 Por. T. Segev, op. cit., s. 30-35. 
się z prośbą o wsparcie finansowe do Związku pomocy Żydom w Niemczech lub do wiedeńskiej gminy oświaty. Zdobycie odpowiedniej ilości pieniędzy na przejazd całej rodziny jest często niemożliwe, dlatego też przede wszystkim dąży się do wysłania za granicę, w tym czasie szczególnie zagrożonych, mężczyzn młodego i średniego wiekowo pokolenia, po ich pobycie w obozie koncentracyjnym lub w więzieniu. W latach 1937-1941 przybywa do Szanghaju od 18 do 20 tys. uciekinierów z Niemiec, w tym jedna czwarta z Austrii; ok. 1000 z Polski i kilkuset z Włoch, Szwajcarii, Czechosłowacji, Rumunii i Węgier ${ }^{47}$. Wielu z tych, którzy przeżyją emigrację przeprowadzi się po wojnie do Palesty.ny/Izraela.

Podobna do wyżej opisanej możliwości ucieczki - w ostatniej chwili - ma też miejsce do Ameryki Łacińskiej, a w szczególności do Boliwii. Wymagane tu wizy wjazdu zdobywa się legalnie lub też, jak można dowieść w przy padku wszystkich innych państw, nielegalnie - za pomocą przekupstwa. Również tutaj wybiera się $\mathrm{z}$ dużych rodzin osoby najbardziej zagrożone, nowożeńców, młodych mężczyzn, którzy udają się w drogę z przyzwoloną przez NS reżim sumą pieniędzy w wysokości 10 marek i z kilkoma zaledwie sztukami bagażu ${ }^{48}$.

Organizacja Aliyat Hanoar lub Młodzież - Aliya, założona w 1932 roku przez Rechę Freier, żonę rabina, która stawia sobie za cel ratunek żydowskich dzieci z Niemiec, wysyła dzieci i młodzież nie tylko do Palestyny, ale też do innych krajów Europy. Organizacja ta legalnie współpracowała $z$ odpowiednimi urzędami i dbała o to, aby młodzi emigranci mieli aktualne papiery. Dużo inwestuje ona również $\mathrm{w}$ kształcenie swoich podopiecznych, szczególnie w kształcenie zawodowe, przywiązując mniejszą wagę do preferowanego przez syjonistów szkolenia rolniczego. Aliyat Hanoar staje się później częścią Jewish Agency, a Rechę Freier zastępuje Henrietta Szold ${ }^{49}$. W ostatnich latach organizacja zajmuje się głównie młodymi emigrantami z Etiopii i Rosji. W tym momencie ze względów partyjno-politycznych rozważa się rozwiązanie organizacji lub przyłączenie jej do Ministerstwa do Spraw Rodziny.

- Przez transport dzieci do Wielkiej Brytanii:

Pogromy z 9 listopada wyraźnie pokazują społeczeństwu brytyjskiemu sytuację narodu żydowskiego w Niemczech. Dzięki wsparciu, tworzonych

47 Por. Jïdisches Museum im Stadtmuseum Berlin (wyd.), Leben im Wartesaal. Exil in Shanghai 1938-1947, Berlin 1997, s. 12-16.

48 Por. W. Seelisch, op. cit., s. 93-95.

49 Por. T. Segev, op. cit., s. 225-228. 
w Wielkiej Brytanii od 1933 roku organizacji niosących pomoc dla żydowskich emigrantów i ich dzieci, takich jak komitet Children's Inter Aid, fundusz Safe the Children, udaje się wpływowej grupie kwaków i Żydów nakłonić rząd brytyjski do wystawienia „nieograniczonej liczbie dzieci do 17 roku życia pozwoleń na wjazd do Wielkiej Brytanii z Niemiec, Austrii (później zajętej Czechosłowacji)", pod warunkiem, że ich pobyt będzie finansowany albo ze środków własnych lub też przez inne osoby prywatne. Kierownictwo tych akcji ratowniczych przejmuje ruch opieki nad dziećmi uciekinierów z Niemiec i Austrii Movement for the Children Care from Germany, który później działa pod nazwą Refugee Children's Movement i początkowo znajduje się pod przewodnictwem Normanna Bentwicka i jego żony. Fundusz powołany przez byłego premiera lorda Balvina może wykazać się sześć miesięcy później zebraną sumą pieniędzy w wysokości 500000 funtów szterlingów. Ludność brytyjska czuje się zachęcona i reaguje otwierając swoje domy, tzn., że nie tylko istniejące i aktywnie działające organizacje mogą umieszczać w swoich domach żydowskie „transporty dzieci”, lecz również chrześcijanie i Żydzi, pojedyncze osoby i rodziny deklarują wziąć pod swoją opiekę chłopców i dziewczynki, czasem nie mających jeszcze trzech lat ${ }^{50}$.

Zdaniem organizatorów, idealnemu obrazowi rodziny opiekuńczej odpowiada rodzina należąca do wyższej warstwy społecznej i posiadająca własną rodzinę. Najlepiej jakby mieszkali na wsi, mówili po niemiecku i byli w stanie tolerować dzieci depresyjne, które w milczeniu muszą znieść swój los z dala od rodziny i ojczyzny. Powinni oni też próbować stworzyć tym dzieciom nowy dom.

Rzeczywistość wygląda jednak inaczej. Tego typu zastępczy rodzice są wyjątkiem. Ci, którzy zgłaszają się, aby przyjąć dzieci należą głównie do niższych warstw społecznych lub do rodzin robotniczych. Zamieszku ją małe domy na obrzeżach większych lub mniejszych miast, mają już dorosłe dzieci, albo wcale ich nie mają. Mówią tylko po angielsku, a o Niemczech wiedzą tyle, ile przeczytają z nagłówków w Daily Express, Daily Mirror lub też $z$ historyjek $z$ artykułów zawartych na pierwszych stronach gazet. Nie są te $\dot{z}$ Żydami i nie mają żadnego doświadczenia $\mathrm{z}$ obchodzeniem się z traumatycznymi przeżyciami dzieci żydowskich ${ }^{51}$.

Wspomnienia dotyczące wyboru dzieci po ich przybyciu do Wielkiej Brytanii są „często podobne do wyglądu rynku bydła: potencjalni rodzice

50 Por. B. Turner, Kindertransport Eine beispiellose Rettungsaktion, Gerlingen 1994, s. 7-12.

51 Por. ibidem, s. 119. 
zastępczy pojawiali się zazwyczaj w stołówce podczas posiłków i wyszukiwali dzieci, które miały u nich mieszkać. Im dziecko było młodsze tym miało większe szanse na znalezienie miejsca w zastępczej rodzinie. Do tego szczególnym powodzeniem cieszyły się dziewczynki o blond włosach i niebieskich oczach - wg ideologii nazistowskiej - o aryjskim wyglądzie. Trudniej zaś było znaleźć miejsce w zastępczej rodzinie dla wysokich chłopców o ciemnych włosach ${ }^{52}$.

Nowa ojczyzna oznacza dla dzieci ogromną przemianę, której muszą dokonać bez pomocy rodziców lub rodziny. Inne jedzenie, niezrozumiały język - tylko niewielu uczyło się angielskiego w szkole lub u prywatnych nauczycieli, a i ci często nie dają sobie rady, gdyż potoczny język środowiska robotniczego lub otoczenia rolniczego jest bardzo niezrozumiały. Nowe obyczaje i formy zachowań są często obce i irytujące. Część dzieci ma duże trudności innego typu. Są one zaniedbywane i wykorzystywane w swoich rodzinach jako tania siła robocza. Inna zaś część dzieci chętnie wspomina rodziny zastępcze i do dzisiaj utrzymuje z nimi przyjacielskie kontakty.

Najtrudniej jest dla dzieci z domów bardzo religijnych lub ortodoksyjnych. Muszą one spożywać niekoszerne jedzenie i nie mogá świętować sabatu. Kultywowane w gronie rodziców, dziadków i innych członków rodziny tradycje zostają ucięte, passé.

Aktywne organizacje pomagające żydowskim dzieciom starają się przynajmniej w większych miejscowościach - również jako punkt wyjściowy dla możliwości pobytu dzieci w bardziej odległych miejscach - zorganizować szkołę, w której chłopcy uczyliby się i przygotowywali do bar micwy. Rabini, którzy odprawiają tam w sabat nabożeństwa, pochodzą po części z byłych ortodoksyjnych wspólnot żydowskich z Niemiec, Czechosłowacji lub są wysyłani z Palestyny ${ }^{53}$.

Ze względu na fakt, że większość dzieci żydowskich pochodzących $z$ rodzin ortodoksyjnych nie mogła zostać skierowana do rodzin żydowskich, gdyż tylko część członków gmin żydowskich jest gotowa i chce, lub też jest w stanie przy jąć żydowsko-aszkenackie dzieci z Niemiec, Zjednoczenie Ortodoksyjnych Gmin Izraelskich (ADATH) zarzuca organizacjom pomagającym żydowskim dzieciom „za pomocą utajonego spisku, faworyzowanie chrześcijańskiej gościnności, chęć zniszczenia ortodoksyjnego żydostwa" ${ }^{54}$. Ów ab-

52 R. Göpfert (wyd.), Ich kam allein. Die Rettung von 10.000 jüdischen Kindern nach England 1938/39, z angielskiego Susanne Röckel, Monachium 1994, s. 14.

53 Por. ibidem, s. 15.

54 B. Turner, op. cit., s. 120. 
surdalny zarzut nie uwzględnia faktu, że cała gmina żydowska w Wielkiej Brytanii liczyła wówczas niecały $1 \%$ ludności i że większa jej część należała do średniej, niższej klasy zarobkowej i jak każdy przeciętny Brytyjczyk w tym czasie musiała poradzić sobie mając ok. 4 funtów tygodniowo na przeżycie.

Dzieci, dla których nie udaje się znaleźć rodzin zastępczych, umieszczane są w różnych domach po całej Wielkiej Brytanii: w pustych budynkach szkolnych, nieprzepełnionych jeszcze internatach, na pensjach lub w zamkach udostępnianych przez angielskich magnatów ${ }^{55}$.

Życie w tego typu miejscach pobytu często było związane z militarną dyscypliną, która dla wielu dzieci i młodzieży była czymś zupełnie nieznanym. Trzeba też dodać, że to właśnie Młodzież-Aliya, ale również (inne) organizacje syjonistyczne wykorzystywały tę możliwość, a by kształcić dzieci i młodzież - szczególnie $\mathrm{z}$ odpowiednim pochodzeniem rodzinnym - w zakresie Haschscharah. Ogromnie ułatwiło to sytuację dla wielu z tych, którzy po roku 1935 emigrowali do Palestyny. Między grudniem 1938 roku a wrześniem 1939 organizacje niosące pomoc dzieciom uciekinierów mogą przy jąć w Wielkiej Brytanii 9.354 dzieci, z tego 7.483 pochodzenia żydowskiego, poza tym 431 dzieci, za które w miesiącach poprzedzających noc kryształową poręczyła Inter-Aid oraz ok. 700 dzieci z Młodzież-Aliya i 100 z żydowskich rodzin ortodoksyjnych.

Wybuch wojny oznacza dla dzieci kolejne zmiany. Ci, którzy w międzyczasie osiągnęli wiek 16 lat są niezwłocznie internowani jako enemy allies, część z nich na Isle of Man, inni do obozów interwencyjnych w Walii i Szkocji 56 .

Kiedy nazistowskie siły lotnicze zaczyna ją bombardować Wielką Brytanię, bezsilność przed terrorem bomb objawia się w niektórych przypadkach wzgardą, a nawet nienawiścią, którą daje się odczuć dzieciom. Dla większości jednak oznacza to ewakuację w głąb kraju; nowe, nieznane i bardziej ograniczone przestrzennie środowisko życia.

Do wszystkich zagrożeń dochodzi troska, strach i niepewność związane $z$ losem rodziców i rodzin. Tylko niewielu rodzicom udaje się uciec do Wielkiej Brytanii, ale i w tym przypadku spotkania nie są rzeczą łatwą, gdyż rodzice nie są w stanie wziąć dzieci pod swoją opiekę. Utrudniało to również stosunki z rodziną opiekuńczą. Inne dzieci otrzymują nieregularną pocztę.

55 Ibidem, s. 14

56 Por. B. Turner, op. cit., s. 118. 
Pewnego dnia jednak wiadomości przestaja pojawiać się, a z czasem przychodzi list od jakiegoś krewnego, który informuje o transporcie na Wschód, o śmierci. Wiele dzieci jest tak małych, że migawkowe wrażenia z ucieczki, przybycie i życie w Wielkiej Brytanii przykrywają wspomnienia o rodzicach, wypierają obraz ich wyglądu i dźwięk ich głosu. „Ale właśnie ta pamięć o umarłych, wspomnienia o nich odgrywaja w kulturze żydowskiej szczególną rolę, a kiedy nie zna się ani miejsca, ani daty ich śmierci, ...i nie istnieje żaden grób to przez całe życie trudno jest przejść żałobę po utracie rodziców, czy innych członków rodziny." Do tego dochodzi poczucie winy, że jako dziecko samemu się przeżyło i że nie zrobiło się wystarczająco dużo, aby umożliwić przeżycie rodzicom ${ }^{57}$.

\section{Warunki początkowe}

Grupa pierwsza: członek syjonistycznej organizacji w Niemczech lub Europie Środkowej, odpowiednio ustawiony ideologicznie, był w Haschscharah: „Kiedy taka osoba przybywa do kraju otrzymuje wsparcie, którego potrzebuje. Przyjmuje się ją do kibucu, gdzie nie jest jednak łatwo, gdyż mieszka się w namiotach lub prostych chatach (obok namiotów dzieci często słychać wycie kojotów). Trzeba wykonywać wyznaczone prace, których się wcześniej nigdy nie uczyło. Dzieci są brane do domów dziecka, co dla wielu przybywających do kraju po 1945 nie jest wystarczająco przekonywujące. W UI Pan uczy się języka, ale jest się na tyle przekonanym o syjonistycznych celach, że pozostaje się w kibucu do dzisiaj.

Grupa druga: posiada się syjonistyczne pochodzenie, ale w wyniku różnych przeżyć i doświadczeń nie można go kultywować. Jeśli się przeżyje i przybędzie do Palestyny, idzie się do kibucu, ale nie zna się tam nikogo osobiście. Brakuje związku z Haschscharah. Pobyt w kibucu staje się „piekłem” i powodem dla którego opuszcza się go. Niedogodność ta występuje również przy próbie integracji ze społeczeństwem i przy poszukiwaniu pracy. Poczucie wyższości sabrów może ich spotkać na każdej płaszczyźnie. Wzgarda walczących w getcie dotyka. Wielu z nich rozczarowuje się i opuszcza Izrael.

Grupa trzecia: przeżyła np. dzięki transportowi dzieci. Jest aktywna w Wielkiej Brytanii tylko w ramach gospodarstw domowych. Po wojnie wolno jej było opuścić Wielką Brytanię i wyjechać do Palestyny, gdzie ma

57 R. Göpfert (wyd.), op. cit., s. 161, wywiad z Ester Golan. 
krewnych, którzy przyjechali tam podczas tych trzydziestu lat. Podczas pierwszych miesięcy pobytu krewni oferuja pomoc. Fizyczne, materialne i rodzinne więzy są silniejsze od uprzedzeń wobec tych, którzy nie walczyli. Osiągnięcie stabilności materialnej jest trudne, ale dzięki rodzinnym stosunkom po pewnym czasie udaje się.

Grupa czwarta: przeżywa shoah w podziemiu. Przybywa do Palestyny gdzie ma tylko bardzo dalekich krewnych, którzy sami znajdują się w trudnej sytuacji materialnej, tak że nie są w stanie udzielić pomocy. Żyje więc w bardzo złych warunkach. Nie otrzymuje też żadnej pomocy od państwa, gdyż jest ono zbyt obciążone organizacy jnie i nie dysponuje odpowiednimi środkami do udzielenia pomocy socjalnej. Doświadcza się poniżenia ze strony sabrów, tym bardziej kibucczyków. Czuje się nie tylko ludźmi drugiej kategorii, ale wręcz sługami. Bardzo powoli, konkuru jąc z imigrantami z krajów orientalnych, udaje jej się jednak wybić.

Ludziom z grupy drugiej i czwartej okazuje się wciąż bardzo wyraźnie, że nie są mile widziani w Jishuw, że są postrzegani jako „konkurencja” w walce o przeżycie. Wyraża się w stosunku do nich wszelkie uprzedzenia, jakie tylko można mieć do „innych". Posługuje się przesadą specyficzną dla danego środowiska, która często jest oparta na „wrogości do wrogów”. Wymaga się od nich powrotu do swoich krajów. Pyta się ich dlaczego Hitler nie zabił ich w gazowych komorach. 